\title{
Migration and Regional Unemployment in Italy
}

\author{
Roberto Basile $^{*}, 1$, Alessandro Girardi ${ }^{2}$ and Marianna Mantuano ${ }^{2}$ \\ ${ }^{I}$ Seconda Università di Napoli, Dipartimento di Strategie Aziendali, Facoltà di Economia, Corso Gran Priorato di \\ Malta, 1, 81043, Capua (CE), Italy \\ ${ }^{2}$ ISTAT (Italian National Institute of Statistics), Rome, Italy
}

\begin{abstract}
Does interregional migration equilibrate regional labor market performances? We answer this question focusing on regional unemployment dynamics in Italy over the 1995-2006 period, when a strong flow of out-migration from the South to the North occurred. Using System-GMM estimators for spatial dynamic panel data models in the presence of endogenous variables, the empirical analysis documents that past migration flows exert a negative effect on current regional unemployment. By falsifying the common wisdom, our results thus indicate that migration flows are likely to magnify spatial disparities in unemployment rates rather than mitigate them.
\end{abstract}

Keywords: Italy, migration, regional labor markets, dynamic panel models, spatial dependence, unemployment.

\section{INTRODUCTION}

Lowering unemployment is a policy mission typically challenged at the national level. Only in the textbook case of efficient local labor markets with homogenous labor and spatially and serially uncorrelated idiosyncratic random shocks, labor mobility eliminates spatial disparities in unemployment rates, so as persistent regional differentials can only be ascribed to labor markets rigidities, which tend to discourage workforces to move across regions $[1,2]$.

The consequences of interregional labor migration basically change once these assumptions are somewhat relaxed. First, even within a neoclassical framework with the more realistic assumptions of both serially correlated and spatially clustered demand shifts, the expected effect of labor migration is not one of equalization in unemployment rates, but rather the translation of potentially divergent trends into a stable pattern of differentials. Moreover, recent contributions within the New Economic Geography literature have emphasized that, in the presence of agglomeration forces, migration flows are likely to magnify spatial disparities in unemployment rates rather than mitigate them [3]. Finally, using 'brain drain' argumentations, Suedekum [4] has emphasized the spatial diverging effect of labor migration.

The discussion above suggests that the effect of labor migration on interregional unemployment differentials is mostly an empirical question. This paper aims at assessing the ultimate effect of migration on regional unemployment in Italy by using data at the province level (NUTS-3 regions) available for the period 1995-2006. The case of Italy is peculiar since the ongoing restructuring of the domestic labor market has been leading to a reduction of the nationwide unemployment rate in the presence of remarkable (and

*Address correspondence to this author at the Seconda Università di Napoli, Dipartimento di Strategie Aziendali, Facoltà di Economia, Corso Gran Priorato di Malta, 1, 81043, Capua (CE), Italy; Tel: +39-3389577637;

E-mail: roberto.basile@unina2.it persistent) regional disparities [5-7]. During the same period, a strong flow of out-migration from Southern towards Northern regions has been started. Recent analyses confirm the persistence of this phenomenon: in 2009 over 100,000 people have migrated from the South to the Centre-North, about 40 per cent more than in the opposite direction (form Centre-North to South) [8].

In an effort to better analyze the effects of migration on regional unemployment dynamics, we propose a methodological framework based on dynamic spatial panel data models with endogenous variables [9-11]. Estimation results point out the lack of the equilibrating effect of labor migration on interregional unemployment disparities predicted by the neoclassical approach. We document indeed that recent interregional migration flows in Italy have amplified spatial differentials in unemployment rates. Our empirical findings also show the existence of spatial spillovers in unemployment dynamics in line with Overman \& Puga [12].

The layout of the paper is the following. Section 2 discusses the role of migration on regional unemployment both from a theoretical and an empirical perspective. Section 3 presents the data and the variables used in the econometric analysis. Section 4 illustrates the model specification and the econometric method. Section 5 discusses the estimation results. Concluding remarks follow.

\section{THE EFFECT OF LABOR MIGRATION ON REG- IONAL UNEMPLOYMENT DISPARITIES: THEORETI- CAL CONTROVERSIES AND EMPIRICAL DISPUTES}

\subsection{Positive or Negative Effect?}

The question whether interregional migration equilibrates regional economic performances is an issue fraught with controversy [13]. According to standard neoclassical general equilibrium models of the space-economy with equally skilled workers, labor mobility works as an equilibrating mechanism. If workers move from low-wage to high-wage areas, the increase in labor supply will reduce the wage level 
in the destination region. When wages are rigid, labor mobility will affect regional unemployment.

With temporally and spatially uncorrelated demand shocks and ruling out other possible equilibrating mechanisms (e.g. via capital mobility, product market competition or induced technology changes), the expected equilibrium involves only compensated variations in unemployment rates. In the long-run regional unemployment disparities can indeed only be determined by factors that impede or reduce regional mobility, such as frictional effects of distance and transaction costs, regional amenities that compensate for lower wages or for a higher risk of unemployment [14-16].

With the more realistic assumption of both serially correlated and spatially clustered demand shifts, the expected effect of labor migration is not one of equalization in unemployment rates, but rather the translation of potentially divergent trends into a stable pattern of differentials.

Moreover, once possible production or demand externalities are taken into account, the effect of interregional labor migration on regional unemployment is reversed and labor mobility is likely to magnify regional disparities. In this respect, several works identify as causae
Another body of empirical research has produced sizable evidence from regression models designed to analyze the effect of regional migration on spatial unemployment differentials. Groenewold [19] finds that inter-regional equilibrating forces are slow and do not help equalize regional unemployment rates in Australia. For the case of Canada, Wrage [20] documents a small but significant symmetric effect of migration on regional unemployment rates (i.e., out-migration has an equal but opposite impact to in-migration). Consequently, the ultimate effect of migration on regional unemployment depends on whether or not a region has a net gain or loss of migrants. Empirical studies on Eastern European countries (see Rutkowski \& Pryzbila [21] for Poland; Kertesi [22] for Hungary) also provide evidence that net-migration flows are positive in low-unemployment regions and negative in high-unemployment regions, as the neoclassical paradigm would posit, but they are insufficient to compensate large unemployment differentials.

\section{DATA AND VARIABLES}

\subsection{Unemployment Dynamics}

In order to assess the effect of internal migration on regional unemployment disparities, we exploit longitudinal

Table 1. Descriptive Statistics

\begin{tabular}{|c|c|c|c|c|}
\hline & Mean & Overall Standard Deviation & Between Standard Deviation & Within Standard Deviation \\
\hline \hline Unemployment rate & 9.238 & 6.080 & 5.692 & 2.204 \\
\hline Net Migration rate & 0.018 & 0.311 & 0.304 & 0.072 \\
\hline In-migration rate & 0.384 & 0.162 & 0.150 & 0.062 \\
\hline Out-migration rate & 0.367 & 0.306 & 0.303 & 0.052 \\
\hline Supply-demand mismatch & 0.907 & 0.061 & 0.057 & 0.022 \\
\hline Unit labour cost & 0.689 & 0.071 & 0.044 & 0.056 \\
\hline
\end{tabular}

causarum Kaldorian-like cumulative causation effects originated by selective migration $[17,18]$ or New Economic Geography-style agglomeration effects activated by labor inflows [3].

\subsection{Previous Empirical Evidence}

A group of empirical studies focused on the effectiveness of migration as mechanism of adjustment of negative shocks hitting local labor markets. Sufficiently large labor mobility coupled by massive wage differentials may help absorb negative shocks. In fact, if wages reflect adequately local unemployment rates, then depressed high-unemployment regions may be favored if the unemployed move towards low-unemployment but high-wage regions. This type of adjustment mechanism seems to work in a different way in the US and in the EU, producing different outcomes in terms of employment and inactivity rates. For the case of the US, Blanchard \& Katz [1] find that labor mobility has been crucial in achieving regional convergence in unemployment rates. For the case of the EU, Decressin \& Fatàs [2] find that interregional unemployment convergence was achieved through a reduction in the activity rate in high unemployment regions rather than by labor migration. data for 103 NUTS-3 Italian regions and twelve years (from 1995 to 2006). ${ }^{1}$ The dependent variable is the logarithm of the annual provincial unemployment rate, $\ln u_{t}$. Descriptive statistics for the variables are reported in Table $\mathbf{1}$.

During the sample period, the national-wide unemployment rate has dropped from 11.2 percent in 1995 to 6.8 in 2006, although the dichotomy between CentreNorthern and Southern regions has increased. ${ }^{2}$ The South/Centre-North unemployment rate ratio has indeed moved from 2.3 in 1995 to 3.2 in 2000 as the result of substantially invariant unemployment rates in the South (roughly 18 percent) coupled by a declining pattern in the Centre-North (from 8 to 6 percent). Over the current decade, instead, we observe a slight reduction in the North-South divide, which has led to a ratio of 2.8 in 2006 (Fig. 1).

\footnotetext{
${ }^{1}$ When not differently indicated, all data are taken from the Italian National Institute for Statistics (ISTAT)

${ }^{2}$ In the Italian case, it is customary to distinguish between Southern regions, or interchangeably Mezzogiorno (namely, Abruzzo, Molise, Campania, Puglia, Basilicata, Calabria, Sicilia and Sardegna) and Central-Northern regions (namely, Piemonte, Valle d'Aosta, Lombardia, Trentino Alto Adige, Veneto, Friuli Venezia Giulia, Liguria, Emilia Romagna, Toscana, Umbria, Marche and Lazio).
} 


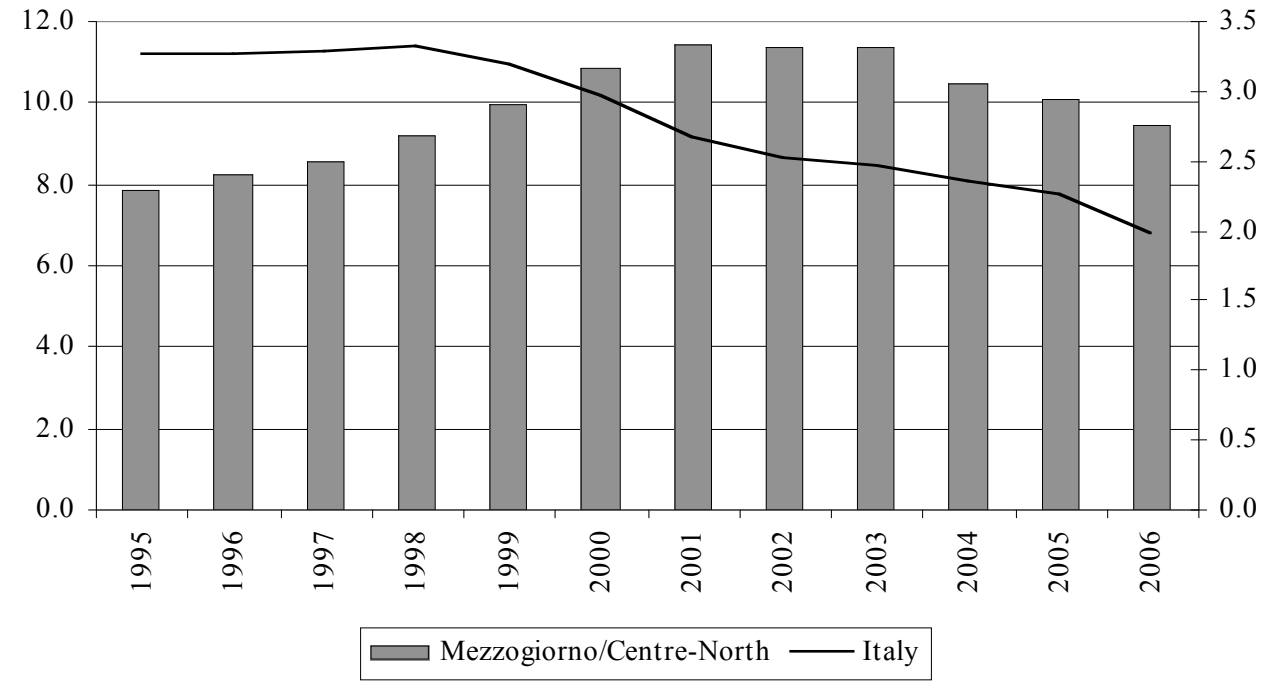

Fig. (1). National unemployment rate and North-South divide: 1995-2006.

An even stronger spatial heterogeneity in labor market performances can be detected at a finer territorial level and such heterogeneity has increased over time. Fig. (2) shows the densities of provincial relative unemployment rates in 1995 (solid line) and in 2006 (bold line). ${ }^{3}$ It emerges a unimodal right-skewed distribution of provincial unemployment rates in 1995, with a higher density for values lower than the national average. The distribution of provincial unemployment in 2006 appears markedly different. We observe a tendency towards polarization, with the main peak much more pronounced than in 1995 and a second lower peak at 1.5 times the national average. Specifically, only one third of Southern provinces show a reduction of unemployment rates like the one observed for the Centre-North, with the remaining Southern provinces entrapped in a condition of high unemployment.

\subsection{Migration Rates and Other Determinants}

The net migration rate (measured as the average net migration balance divided by total population aged 15 64, Net migr ${ }_{t}$ ) constitutes the key causative determinant of regional unemployment in our study. Migration data are derived from a survey ("Indagine sui trasferimenti di residenza") carried out by ISTAT. The average net migration balance is measured as the difference between the number of registrations and the number of cancellations of people aged 15-64 (working population) from the municipality registry. Specifically, we select only long-distance migration flows, that is those originated from the South to the North and viceversa. ${ }^{4}$ In our estimation strategy we also consider possible asymmetric effects of in-migration and outmigration by including separately the (log of the) inmigration rate $\left(\ln \operatorname{In~migr~}_{t}\right)$ and out-migration rate ( ln Out migr $r_{t}$ ).

As documented by Daveri \& Faini [24] and Fachin [25], among others, after the intense migration flows registered

\footnotetext{
${ }^{3}$ Density estimates have been computed by using a local linear estimator with variable bandwidth selected by generalized cross-validation [23].

${ }^{4} \mathrm{We}$ exclude foreign migrants from our analysis.
}

during the 1950s and the 1960s mainly from rural Southern areas to urban Northern regions, a declining of out-migration of labor forces from the South of Italy to the rest of the country occurred from the 1970s, in contradiction with the increase or the maintenance of North-South economic disparities in terms of per-capita income and unemployment rate. The negative trend in internal migration continued until the mid-1990s when a 'new' interregional migration movement from the South to the North started. Fig. (3) documents the increasing out-migration from the South to the North during the second half of the 1990s and a stationary evolution during the following six years. The netmigration rate from the South to the North was negative over the whole sample period with a strong heterogeneity across provinces (see Appendix 1), giving support to our choice of using this level of territorial unit in the econometric analysis.

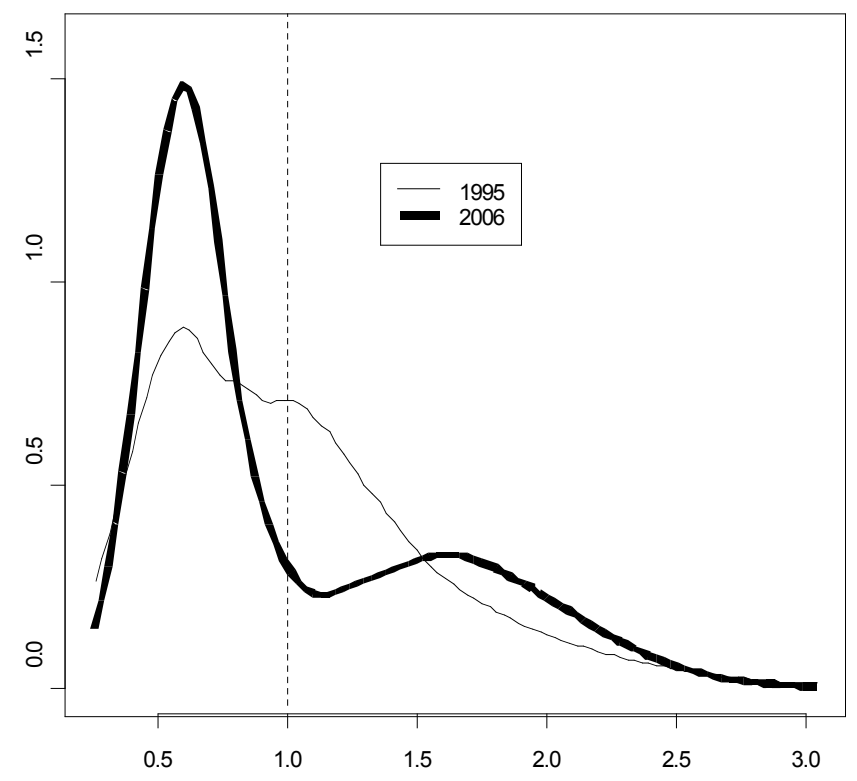

Notes: Provincial unemployment rates have been normalized with respect to the national average.

Fig. (2). Density estimation of provincial unemployment rates: 1995 and 2006. 


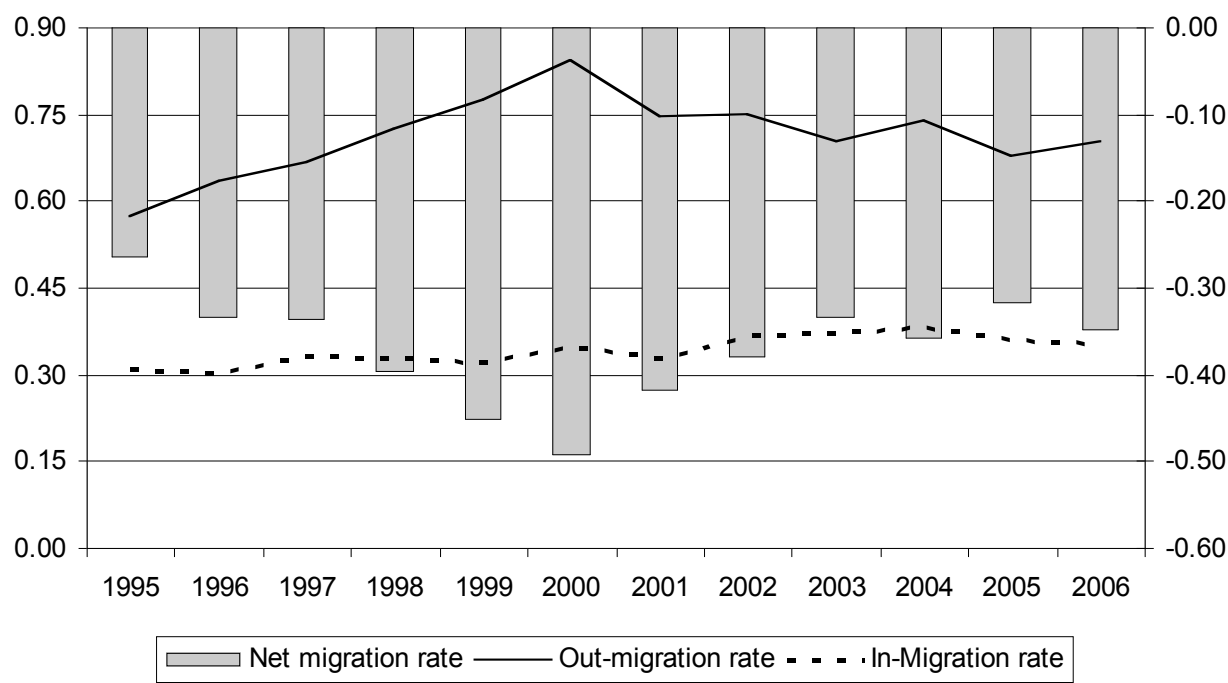

Notes: In-migration rate = In-flow/population*100; Out-migration rate = Out-flow/population*100; Net-migration rate = In-migration rate minus Out-migration rate. We consider in-flows, out-flows and population aged between 15 and 64 (i.e. working population).

Fig. (3). Migration rate from South to Centre-North Italy: 1995-2006.

In keeping with the existent empirical literature, the dynamics of regional unemployment rates is likely to depend on additional factors so as we exploit the available information at NUTS-3 level to build up other two important variables suggested in the literature. ${ }^{5}$ Thus, we include in the set of regressors a measure of excess labor demand (or supply-demand mismatch), that is the difference between the $\log$ of the employment rate and the log of the participation rate, $\ln e l d_{t}$. Its expected effect is negative almost by definition. Furthermore, we include the unit labor cost $\left(\ln u l c_{t}\right)$, defined as the (log of the) ratio between average wages and labor productivity: a higher labor cost is expected to exert a negative effect on labor market performances, so that we expect a positive impact of $\ln u l c_{t}$ on the response variable.

\section{EMPIRICAL FRAMEWORK}

\subsection{A Spatial Dynamic Panel Model Specification}

In order to analyze the effect of internal migration on regional unemployment disparities in Italy, we rely on the spatial lag framework suggested by Overman \& Puga [12]

$$
\begin{aligned}
\ln \left(u_{T, i} / u_{0, i}\right)= & \alpha+\beta \ln u_{0, i}+\rho \sum_{j=1}^{N} w_{i j} \ln \left(u_{T, i} / u_{0, i}\right) \\
& +\sum_{k} \gamma_{k} X_{k, i}+\varepsilon_{i}
\end{aligned}
$$

where $i=1, \ldots, N$ are the spatial units of analysis and $W=\left\{w_{i j}\right\}_{i \neq j}$ is a pre-specified non-negative square matrix of order $N$ collecting spatial weights, $w_{i j}$, which describe the spatial arrangement of the units in the sample. In model (1),

${ }^{5}[11]$ gives a comprehensive description of the variables included in recent empirical analyses on regional unemployment differentials. In a preliminary econometric analysis, we considered other potential determinants of regional unemployment (specifically human capital, market potential and industry mix), but these variables did not turn out to be robust determinants of regional unemployment using our sample. growth rates of regional unemployment, $\ln \left(u_{i, T} / u_{i, 0}\right)$, between the initial $(0)$ and the final period $(T)$ are regressed on initial conditions, $\ln u_{i, 0}$, on a set of explanatory variables, $X$, and on neighbors' unemployment growth rates, $\sum_{j=1}^{N} w_{i j} \ln \left(u_{T, i} / u_{0, i}\right)$. The reduced form of this specification implies that the unemployment rate dynamics in a given location will be affected not only by its characteristics, $X$, and by its idiosyncratic shocks $\left(\varepsilon_{i}\right)$, but also by those in all other regions through the inverse spatial transformation $(I-\rho W)^{-1}$.

The introduction of the spatial lag term in unemployment regression analysis is justified on the basis of various argumentations. First, regions are tightly linked by migration, commuting and interregional trade. These types of spatial interaction are exposed to the frictional effects of distance, possibly causing the spatial dependence of regional labor market conditions. Even though we control for SouthNorth labor migration, spatial dependence may still arise due to un-modeled commuting effects. Second, spatial dependence may be the result of agglomeration effects related to the demand linkages across nearby areas [13]. Third, the spatial lag term may act as a proxy for omitted time-varying variables clustered in space, so that omitting spatial autocorrelation may lead to misleading estimates and inference [26].

As proposed in the economic growth literature by Bouyad-Agha \& Vedrine [27] and $\mathrm{Yu} \&$ Lee [28], it is possible to extend this cross-section framework towards a dynamic spatial lag panel model:

\footnotetext{
${ }^{6}$ As for the construction of spatial weight matrix, we have chosen a pure geographical definition of neighborhood based on the Euclidean distance between regions. More precisely, we have chosen a $k$-nearest neighbors weight specification, with $k$ equal to $5,10,15$ and 20 .
} 


$$
\begin{aligned}
\ln u_{i, t}= & \theta \ln u_{i, t-1}+\rho_{1} \sum_{j=1}^{N} w_{i j} \ln u_{j, t}+\rho_{2} \sum_{j=1}^{N} w_{i j} \ln u_{j, t-1}+ \\
& \sum_{k} \gamma_{k} E X_{k, i, t}+\sum_{q} \delta_{q} E N_{q, i, t}+\eta_{i}+\lambda_{t}+\varepsilon_{i, t}
\end{aligned}
$$

where $i=1, \ldots, N ; t=1, \ldots, T ; \theta=(1+\beta) ;\left|\theta+\rho_{1}+\rho_{2}\right|<1$; $\varepsilon_{i t} \sim M A(0){ }^{7}$

In model (2), the natural logarithm of the current unemployment rate, $\ln u_{i, t}$, is regressed on lagged $\log$ unemployment rates, $\ln u_{i, t-1}$, on the spatial lag of current and lagged log-unemployment, on a set of exogenous explanatory variables, $E X_{k, i, t}$, and on a set of endogenous variables with respect to $\ln u_{i, t}$. This specification is justified by the observation that unemployment rates usually change by small amounts over time and across regions (see, for example, Elhrost [14]). Thus, if we ignore spatial and serial dynamic effects, our regional unemployment rate equation may be seriously mis-specified. Moreover, the fixed spatial effects, $\eta_{i}$, allow to control for unobserved spatial heterogeneity, while the fixed temporal effects, $\lambda_{t}$, permit to control for common national factors affecting regional unemployment dynamics.

Different authors have proposed maximum likelihood (ML) or quasi-ML estimators for dynamic spatial panel models [29-31]. Since these estimators are based on the assumption of only exogenous covariates except for the time and spatial lag terms, various empirical studies dealing with endogeneity issues in a dynamic spatial panel framework have applied the System-GMM (Generalized Method of Moments) estimator. More specifically, Kukenova \& Monteiro [10] have investigated the finite sample properties of different estimators for spatial dynamic panel models (namely, spatial ML, spatial dynamic ML, spatial dynamic quasi-ML, least-square-dummy-variable, Diff-GMM and System-GMM) and concluded that, in order to account for the endogeneity of several covariates, spatial dynamic panel models should be estimated using System-GMM. The main argument of applying System-GMM in a spatial context is that it corrects for the endogeneity of the spatial lagged dependent variable and other potentially endogenous explanatory variables. It also allows taking into consideration some econometric problems such as measurement errors and weak instruments.

\subsection{Time Series Properties}

Before discussing the econometric results, it is important to address two issues related to the order of integration of our variables and to the causality nexus between unemployment and migration rates.

As for the stochastic nature of our relevant variables, it would be interesting to have information about the stationarity of the variables. Note however that our time series are too short (12 years) to properly perform panel unit

\footnotetext{
${ }^{7}$ It is worth noticing that the spatial dynamic panel counterpart of model (1) would imply a restriction on the parameters of the two spatial lag terms, such that $\rho_{1}=-\rho_{2}=\rho$. However, we consider a more general setting by relaxing such a restriction and, thus, allowing $\rho_{1} \neq-\rho_{2}$.
}

root tests (provincial level data on migration are available only from 1995). Nevertheless, we cannot disregard the evidence in favour of a unit root process for interregional migration and unemployment rates (at NUTS- 1 and NUTS-2 level) over the period 1970-1995 provided by recent empirical studies on internal migration in Italy [25, 32]. However, even admitting the possibility of non-stationarity, we rely on the analysis of the asymptotic and finite sample properties of GMM estimators in presence of unit roots and cointegration carried out by Pesaran [33]. He concludes that, while the standard Arellano \& Bond [34] estimator breaks down if the underlying time series contain unit roots, the extended GMM estimators (e.g. the System-GMM) are consistent even if the unit root properties of the model are not known a priori.

\subsection{Reverse Causality Issues}

In relation to the causality nexus between unemployment and migration rates, the literature on internal migration suggests that regional unemployment differentials affect internal migration behaviour $[35,36]$. For the case of Italy and for the period before the new recent wave of internal migration (started in 1995), Daveri \& Faini [24] find a null or negligible effect of unemployment and point at a more prominent role given to regional wage levels in explaining gross out-migration from Southern to Northern regions. Similar evidence is reported in Fachin [25] for long-run trends of Italian South-North migration. However, from the mid-nineties (that is the period we consider in this paper) a significant effect of unemployment on internal migration in Italy has been documented in other empirical analyses $[18$, 32].

In order to assess the direction of causality between regional unemployment and net migration rates, we perform a Granger causality test in a panel vector autoregressive framework using the System GMM estimator [37]. Specifically, we consider the following spatial dynamic panel models with time and region specific effects:

$$
\begin{aligned}
& \ln u_{i, t}=\sum_{p=1}^{m} \theta_{p} \ln u_{i, t-p}+\sum_{p=1}^{m} \sum_{j=1}^{N} \rho_{p} w_{i j} \ln u_{j, t-p}+ \\
& \sum_{p=1}^{m} \beta_{p} \text { Net migr } r_{i, t-p}+\sum_{p=1}^{m} \sum_{j=1}^{N} \varphi_{p} w_{i j} \text { Net migr } r_{j, t-p}+ \\
& \eta_{i}+\lambda_{t}+\varepsilon_{i, t} \\
& \text { Net migr }_{i, t}=\sum_{p=1}^{m} \delta_{p} \text { Net migr }_{i, t-p}+ \\
& \sum_{p=1}^{m} \sum_{j=1}^{N} \gamma_{p} w_{i j} \text { Net migr } r_{j, t-p}+\sum_{p=1}^{m} \phi_{p} \ln u_{i, t-p}+ \\
& \sum_{p=1}^{m} \sum_{j=1}^{N} \psi_{p} w_{i j} \ln u_{j, t-p}+\xi_{i}+\tau_{t}+v_{i, t}
\end{aligned}
$$

The number of lags $(m)$ is specified to be identical for all variables. Since Granger causality test results may depend on the choice of lag specification, we report the results for a maximum lag order of three years and then determine the optimal lag specification based on the Akaike Information Criterion (AIC). The two-step robust System-GMM estimation results are reported in Table $2 .^{8}$ Three main

\footnotetext{
${ }^{8}$ Due to the short length of our time series, we do not report the results of Granger causality tests based on a higher number of lags. However, we have also estimated models with up to five lags and the results (available upon request) do not change the conclusion in favour of the 3-lag model. As for
} 
Table 2. Test of Granger Causality. System-GMM Estimates

From Migration to Unemployment

\begin{tabular}{|c|c|c|c|c|c|c|}
\hline & Lags & Wald Joint Test $p$-Value & AIC & AR(1) & AR(2) & Hansen $\boldsymbol{J}$ \\
\hline \hline Net migr & 1 & 0.000 & 4,160 & 0.000 & 0.129 & 0.144 \\
\hline & 2 & 0.002 & 3,561 & 0.000 & 0.550 & 0.132 \\
\hline & 3 & 0.001 & 3,129 & 0.000 & 0.516 & 0.185 \\
\hline
\end{tabular}

From Unemployment to Migration

\begin{tabular}{|c|c|c|c|c|c|c|}
\hline & Lags & Wald Joint Test $\boldsymbol{p}$-Value & AIC & AR(1) & AR(2) & Hansen $\boldsymbol{J}$ \\
\hline \hline $\ln u$ & 1 & 0.017 & 1,896 & 0.000 & 0.236 & 0.314 \\
\hline & 2 & 0.167 & 1,507 & 0.000 & 0.883 & 0.208 \\
\hline & 3 & 0.267 & 1,290 & 0.000 & 0.954 & 0.127 \\
\hline
\end{tabular}

Notes: p-values are reported for joint significance test for Granger causality. AIC is the Akaike Information Criterion. AR(1) and AR(2) are the Arellano and Bond tests for first and second-order serial correlation, Hansen $\mathbf{J}$ is the over-identification test.

remarks ensue: $i$ ) there is consistent evidence of Granger causality in just one direction, i.e. from migration towards unemployment, regardless of the number of lags included in the model; ii) the AIC values indicate the third lag as the optimal one; iii) the validity of the moment conditions employed in the System GMM framework is never rejected.

In Section 5 we focus on the impact of labor migration on regional unemployment. We modify equation (3.a), also by including control variables for other unemployment determinants $\left(\ln e l d_{t}\right.$ and $\left.\ln u l c_{t}\right)$ :

$$
\begin{aligned}
\ln u_{i, t}= & \sum_{p=1}^{3} \theta_{p} \ln u_{i, t-p}+\sum_{p=0}^{3} \sum_{j=1}^{N} \rho_{p} w_{i j} \ln u_{j, t-p}+ \\
& \sum_{p=1}^{3} \beta_{p} \text { Net migr }_{i, t-p}+\sum_{p=1}^{3} \chi_{p} \ln \text { eld }_{i, t-p}+ \\
& \sum_{p=1}^{3} \pi_{p} \ln u l c_{i, t-p}+\eta_{i}+\lambda_{t}+\varepsilon_{i, t}
\end{aligned}
$$

The exogeneity assumption is clearly violated for $\ln$ eld (the employment rate and the participation rate have common components with the dependent variable by construction) and $\ln u l c_{t}$. In order to reduce these biases we use internal instruments. The System-GMM procedure is also applied to reduce the endogeneity bias deriving from the inclusion of spatial lags of $\ln u_{t}$ and by Net migr $r_{t}$.

\section{THE IMPACT OF MIGRATION ON REGIONAL UNEMPLOYMENT: ESTIMATION RESULTS}

Results from two-step System-GMM robust estimations with Windmeijer [38]'s finite-sample correction of unemployment equation (4) are shown in Table 3. The design of the spatial dynamic panel model specification relies, however, on the spatial weight matrix $W$ describing the spatial arrangement of the cross-section units (see Appendix 2). In order to check the robustness of our analysis

the choice of internal instruments used in the System-GMM procedure, we use five periods lagged levels in differenced equations and one period lagged first-differences in level equations. we estimate the model including the full set of variables by using alternative spatial weight matrices: $5-\mathrm{NN}$ (Column 1), 10-NN (Column 2), 15-NN (Column 3) and 20-NN (Column 4). All models include internal instruments. ${ }^{9}$

Finally, even though the results of Granger causality tests discussed above provide evidence of a significant effect of labor migration on regional unemployment regardless the time lag considered, here we focus on the results based on the longest optimal lag order of three which has the advantage of taking the temporal dynamics of the effects for a longer period into account.

The test statistics of serial correlation $\left(A R_{I}\right.$ and $\left.A R_{2}\right)$, the Hansen test and the $\mathrm{C}$-statistics for the level equation (i.e. the difference of Hansen statistic between the set of instruments of the System-GMM and that of the Arellano-Bond first difference GMM model) indicate that the instruments used in System-GMM estimations satisfy the required orthogonality conditions in all specifications. Relying on AIC values, the model with $10-\mathrm{NN}$ matrix is to be preferred to the others, but the evidences from the four models are consistent with each other.

The Wald tests for the joint significance of the lagged terms reported in Table 3 provide evidence of a significant effect of all the variables included, even though lagged values of $\ln u l c_{t}$ are significant only in specification (1). Thus, we conclude that, even controlling for the lagged effect of unit labor cost and excess labor demand, lagged values of net-migration significantly influence the dynamics

\footnotetext{
${ }^{9}$ An important issue in the application of System-GMM estimators concerns the fact that the number of instruments increases with the sample size $T$ (it is quadratic in $T$ ). A large number of instruments can overfit instrumented variables and leads to inaccurate estimation of the optimal weight matrix, to downward biased two-step standard errors and to wrong inference in the Hansen test [39]. To avoid these problems, we use a restricted set of instruments for GMM estimates. Specifically, the number of instruments is set to two for estimations in differenced equations in that we use two lagged levels in time periods $\mathrm{t}-2$ and $\mathrm{t}-3$ as instruments, while we use one period lagged first-differences for GMM in levels equations.
} 
Table 3. Unemployment Equation. Spatial Dynamic Panel Models with Net Migration Rate. Three-Year Lag Specification. Alternative Spatial Weights Matrix

\begin{tabular}{|c|c|c|c|c|}
\hline Lagged Variable & (1a) $5-\mathrm{NN}$ & (1b) $10-\mathrm{NN}$ & (1c) $15-\mathrm{NN}$ & (1d) $20-\mathrm{NN}$ \\
\hline \multicolumn{5}{|c|}{ Wald Joint Tests } \\
\hline$W \ln u$ & {$[0.000]$} & {$[0.000]$} & {$[0.000]$} & {$[0.000]$} \\
\hline Net migr & {$[0.098]$} & {$[0.071]$} & [0.089] & [0.109] \\
\hline Akaike Inf. Criterion & 3,272 & 3,219 & 3,230 & 3,261 \\
\hline $\mathrm{AR}(1)$ & {$[0.000]$} & {$[0.000]$} & {$[0.000]$} & {$[0.000]$} \\
\hline $\mathrm{AR}(2)$ & {$[0.847]$} & {$[0.454]$} & {$[0.660]$} & {$[0.715]$} \\
\hline Hansen $J$ & {$[0.572]$} & {$[0.701]$} & {$[0.647]$} & {$[0.676]$} \\
\hline $\ln u+W \ln u$ & 0.747 & 0.789 & 0.772 & 0.751 \\
\hline \multicolumn{5}{|c|}{ Short Run Effects } \\
\hline Net migr & -0.240 & -0.200 & -0.157 & -0.120 \\
\hline $\ln$ eld & -1.708 & -1.699 & -1.862 & -2.168 \\
\hline $\ln u l c$ & -0.786 & -0.625 & -0.660 & -0.695 \\
\hline \multicolumn{5}{|c|}{ Long Run Effects } \\
\hline Net migr & -0.701 & -0.656 & -0.511 & -0.362 \\
\hline $\ln$ eld & -4.986 & -5.582 & -6.059 & -6.543 \\
\hline
\end{tabular}

Notes: the dependent variable is the log of the current regional unemployment rate. Explanatory variables are lagged three years. Models are estimated by two-step system robust GMM method in a way to take both temporally and spatially lagged dependent variables as endogenous and to incorporate validity tests and [38]'s finite-sample correction. Although not reported, all models include fixed time effects. p-values in brackets.

of regional unemployment in Italy, corroborating the results of the Granger causality tests discussed above.

The parameters associated to spatial lagged terms are jointly statistically significant; they have opposite signs $\left(\rho_{0}\right.$ is positive while $\rho_{1}, \rho_{2}$ and $\rho_{3}$ are negative), but $\left|\rho_{0}\right|>\left|\rho_{1}+\rho_{2}+\rho_{2}\right|$, thus signalling the presence of global positive spatial spillovers in the labor market. ${ }^{10}$ This implies that the characteristics of province $i$ (for example, its level of net-migration) or an idiosyncratic shock in that province do not only influence the unemployment dynamics in that location, but they also affect the outcome of all other regions with an intensity that decreases with distance [26]. In other words, the coefficients associated to each explanatory variable lose their typical interpretation since a change in a single observation (region) associated with any given explanatory variable will affect the region itself (a direct impact) and potentially affect all other regions indirectly (an indirect or spatial spillover effect) through the spatial multiplier mechanism. The direct impact includes the effect

\footnotetext{
${ }^{10}$ From the Wald test, we see that we can reject the null $\rho_{0}=-\left(\rho_{1}+\rho_{2}+\rho_{3}\right)$, as well as the null $\sum_{p=1}^{3} \theta_{p}+\sum_{p=0}^{3} \rho_{p}=1$.
}

of feedback loops where observation $i$ affects observation $j$ and observation $j$ also affects $i$. Moreover, direct and indirect effects change according to the position of the region in space and, thus, it is customary to measure the average (across regions) direct and indirect effects. The sum of average direct and indirect effects is called the average total effect $(A T E)$. With cross-sectional spatial lag models of the type $y=\beta X+\rho W y+\varepsilon$, we can obtain the $A T E$ for each explanatory variable by simply computing $\beta_{\text {ATE }}=\beta /(1-\rho)$ [26]. In spatial panel dynamic models, we obtain short-run $A T E$ by $\beta_{S R-A T E}=\sum_{p=1}^{3} \beta_{p} /\left(1-\sum_{p=0}^{3} \rho_{p}\right)$ and long-run $A T E$ by $\beta_{L R-A T E}=\sum_{p=1}^{3} \beta_{p} /\left(1-\sum_{p=1}^{3} \theta_{p}-\sum_{p=0}^{3} \rho_{p}\right)$. $^{11}$

Computations indicate that, controlling for spatial dependence, an increase of $1 \%$ in the migration rate leads to

\footnotetext{
${ }^{11}$ Short-run average total effect in spatial panel dynamic models are computed as $\beta_{S R-A T E}=\beta_{S R} /\left(1-\rho_{1}-\rho_{2}\right)$, where $\rho_{1}$ and $\rho_{2}$ are the coefficients of $\sum_{j=1}^{N} w_{i j} \ln u_{j, t}$ and $\sum_{j=1}^{N} w_{i j} \ln u_{j, t-1}$, respectively. Long-run average total effect in spatial panel dynamic models are computed as $\beta_{L R-A T E}=\beta_{S R} /\left(1-\rho_{1}-\rho_{2}-\theta\right)$.
} 
Table 4. Unemployment Equation. Spatial Dynamic Panel Models with In- and Out-Migration. Three-Year Lag Specification. Alternative Spatial Weights Matrix

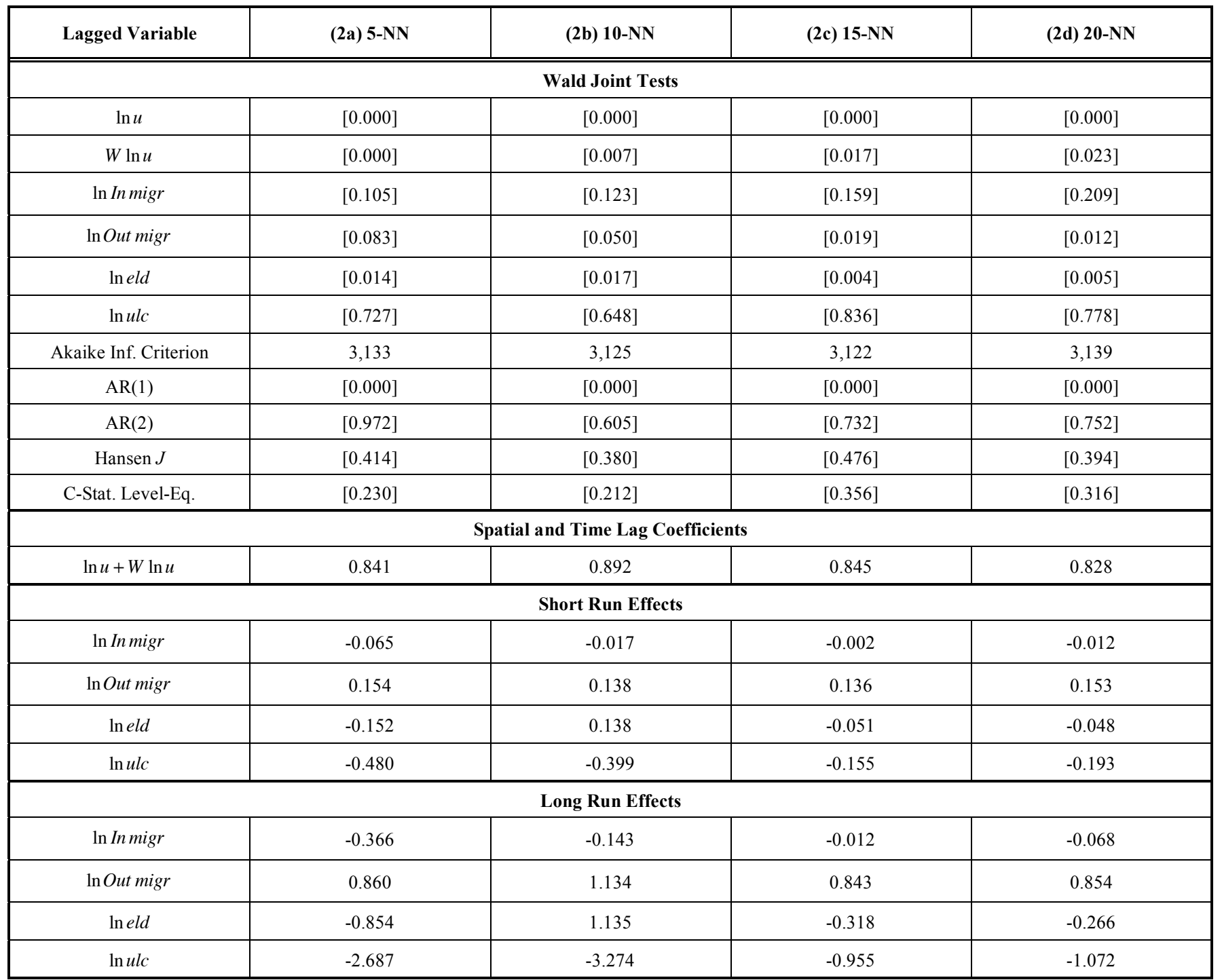

Notes: the dependent variable is the log of the current regional unemployment rate. Explanatory variables are lagged three years. Models are estimated by two-step system robust GMM method in a way to take both temporally and spatially lagged dependent variables as endogenous and to incorporate validity tests and [38]'s finite-sample correction. Although not reported, all models include fixed time effects. p-values in brackets.

a decrease in the unemployment rate in the long run ranging from $0.7 \%$ of Model 1a $(5-\mathrm{NN})$ to about $0.4 \%$ of Model $1 \mathrm{~d}$ $(20-N N)$. This result suggests that demand side effects dominate over supply side (equilibrating) effects, in contrast to the neoclassical prediction and gives empirical support to the idea that workforce outflows worsen local labor market performances, exacerbating the divide between backward areas and the rest of the country. As expected, a higher excess labor demand lowers regional unemployment.

Finally, the sum of the coefficients of the lagged terms of the dependent variable $\left(\sum_{p=1}^{3} \theta_{p}\right)$ ranges between 0.75 and 0.79 , denoting the presence of high persistence.

As an extension, we estimate a model aimed at testing the asymmetric effect of in-migration and out-migration. Thus, the (log of) in-migration and the (log of) out-migration rates are included separately in place of the net migration rate. Results are reported in Table 4. The cumulated impacts of their lagged terms confirm the diverging effect of labor migration on regional unemployment: in-migration is weakly significant only in Model $2 \mathrm{a}$ and it lowers regional unemployment rates; on the contrary, out-migration raises them.

\section{CONCLUDING REMARKS}

This paper aims at assessing whether interregional migration flows equilibrate local labor market performances in Italy. We focus on regional unemployment dynamics at a fine territorial level (103 provinces or NUTS-3 regions) over the 1995-2006 period, during which a strong flow of outmigration from the South to the North occurred. Our results are at odds with the traditional view of migration acting as an equilibrating force for unemployment differentials. Empirical estimates from a number of alternative specifications document that past migration flows have in fact a negative effect on current unemployment rates. This evidence can be rationalized within several theoretical 
frameworks where migration flows magnify spatial disparities in unemployment rates $[3,36]$.

As pointed out by Gordon [40], policy measures aimed at tackling the persistent nature of spatial concentration of high unemployment areas may involve targeted job creation, actions to improve labor market flexibility, or macroeconomic demand management. Targeted job creation policies are likely to be an ineffective way of tackling such concentrations of unemployment for three main reasons: first, the huge costs those actions entail; second; their localized focus may yield to an underestimation of the scale of job creation required to lower unemployment substantially; third, they do not address the key issue of making disadvantaged local residents effective competitors for jobs accruing inside or outside the area.

The evidence of persistent local concentrations of high unemployment regions signals that such a phenomenon is structural in nature and can only be removed by some combination of supply-side measures and sustained fullemployment in the regions concerned. As a consequence, the key problem is not the level of mobility or flexibility, but the uneven way in which processes of mobility and job competition operate. In this respect, supporting measures should include efforts to promote upward mobility among those already in employment, in order to relieve congestion in the occupational sub-markets to which the unemployed can realistically gain access [40].

Possible improvements of the research agenda may include a closer look at migration flows disaggregated by levels of schooling. As pointed out in Mocetti \& Porello [41], indeed, the recent migration out-flows from Southern regions to the rest of Italy have been particularly relevant for high-skilled young workers. As a result, Southern regions appear to be unable to preserve their own human capital with unavoidable detrimental effects not only for local labor market performances but also for long-run local growth. Testing for brain drain effects are left for future research.

\section{ACKNOWLEDGEMENT}

Declared none.

\section{CONFLICT OF INTEREST}

Declared none.

\section{APPENDIX 1}

\section{Migration and Unemployment Rates of Italian Provinces}

Over the sample period, 10 out 36 Southern provinces registered on average a positive net-migration rate, that is an inmigration rate higher than the out-migration rate (Table A1). All other Southern provinces with a negative average netmigration rate (except for Vibo Valentia and Benevento) experienced a drop in the unemployment rate, but only five provinces (Enna, Taranto, Siracusa, Messina and Trapani) performed better than the national average in terms of unemployment growth. In the bottom part of Table A1 we report the 23 Centre-Northern provinces with a positive net migration rate higher than 1 per cent. In 15 cases, the unemployment rate increased more than the national average, but the remaining 8 provinces performed better than the national average. Moreover, we find a negative correlation $(-0.11)$ between provincial net-migration rates and unemployment growth rates.

Table A1. Migration and Unemployment Rates of Italian Provinces Average Values for the Period 1995-2006

\begin{tabular}{|c|c|c|c|c|c|c|c|}
\hline Region & $\begin{array}{l}\text { Macro } \\
\text { Region }\end{array}$ & Province & $\begin{array}{c}\text { Average } \\
\text { In-Mirgation } \\
\text { Rate }\end{array}$ & $\begin{array}{c}\text { Average } \\
\text { Out-Migration } \\
\text { Rate }\end{array}$ & $\begin{array}{c}\text { Average } \\
\text { Net Migration } \\
\text { Rate }\end{array}$ & $\begin{array}{c}\text { Average } \\
\text { Unemployment } \\
\text { Growth Rate }\end{array}$ & $\begin{array}{c}\text { Distance from } \\
\text { National Unemployment } \\
\text { Growth Rate }\end{array}$ \\
\hline Calabria & South & Crotone & 1.43 & 2.36 & -0.94 & -4.06 & 0.48 \\
\hline Sicilia & South & Caltanissetta & 0.97 & 1.64 & -0.67 & -3.87 & 0.67 \\
\hline Sicilia & South & Enna & 1.00 & 1.60 & -0.60 & -6.11 & -1.57 \\
\hline Campania & South & Napoli & 0.70 & 1.29 & -0.59 & -3.97 & 0.57 \\
\hline Calabria & South & Vibo Valentia & 1.23 & 1.83 & -0.59 & 3.22 & 7.76 \\
\hline Sicilia & South & Agrigento & 0.94 & 1.53 & -0.59 & -3.57 & 0.96 \\
\hline Puglia & South & Foggia & 0.83 & 1.39 & -0.56 & -3.33 & 1.21 \\
\hline Puglia & South & Brindisi & 0.91 & 1.34 & -0.44 & -1.00 & 3.54 \\
\hline Calabria & South & Catanzaro & 1.17 & 1.59 & -0.41 & -1.28 & 3.26 \\
\hline Puglia & South & Taranto & 0.79 & 1.17 & -0.38 & -6.87 & -2.33 \\
\hline Calabria & South & Cosenza & 0.95 & 1.32 & -0.37 & -1.69 & 2.84 \\
\hline Calabria & South & Reggio Calabria & 1.16 & 1.52 & -0.37 & -0.76 & 3.78 \\
\hline Sardegna & South & Nuoro & 0.96 & 1.32 & -0.36 & -2.05 & 2.49 \\
\hline Sicilia & South & Palermo & 0.83 & 1.17 & -0.34 & -2.65 & 1.88 \\
\hline Basilicata & South & Matera & 0.95 & 1.26 & -0.30 & -3.02 & 1.52 \\
\hline
\end{tabular}


(Table A1) contd.....

\begin{tabular}{|c|c|c|c|c|c|c|c|}
\hline Region & $\begin{array}{l}\text { Macro } \\
\text { Region }\end{array}$ & Province & $\begin{array}{c}\text { Average } \\
\text { In-Mirgation } \\
\text { Rate }\end{array}$ & $\begin{array}{c}\text { Average } \\
\text { Out-Migration } \\
\text { Rate }\end{array}$ & $\begin{array}{c}\text { Average } \\
\text { Net Migration } \\
\text { Rate }\end{array}$ & $\begin{array}{c}\text { Average } \\
\text { Unemployment } \\
\text { Growth Rate }\end{array}$ & $\begin{array}{c}\text { Distance from } \\
\text { National Unemployment } \\
\text { Growth Rate }\end{array}$ \\
\hline Basilicata & South & Potenza & 0.83 & 1.11 & -0.28 & -4.12 & 0.41 \\
\hline Sicilia & South & Siracusa & 0.92 & 1.19 & -0.27 & -6.57 & -2.04 \\
\hline Puglia & South & Lecce & 0.86 & 1.05 & -0.19 & -1.30 & 3.24 \\
\hline Sicilia & South & Messina & 0.89 & 1.08 & -0.19 & -8.38 & -3.84 \\
\hline Sicilia & South & Catania & 0.79 & 0.96 & -0.17 & -4.19 & 0.35 \\
\hline Sicilia & South & Trapani & 0.87 & 1.03 & -0.16 & -5.14 & -0.60 \\
\hline Sardegna & South & Oristano & 1.02 & 1.16 & -0.14 & -0.07 & 4.47 \\
\hline Puglia & South & Bari & 0.62 & 0.75 & -0.13 & -0.07 & 4.47 \\
\hline Sardegna & South & Cagliari & 0.83 & 0.92 & -0.10 & -4.24 & 0.29 \\
\hline Campania & South & Benevento & 1.10 & 1.18 & -0.08 & 2.28 & 6.82 \\
\hline Campania & South & Salerno & 0.97 & 1.03 & -0.06 & -3.69 & 0.85 \\
\hline Molise & South & Campobasso & 1.09 & 1.06 & 0.03 & -1.24 & 3.30 \\
\hline Campania & South & Avellino & 1.27 & 1.19 & 0.08 & -2.40 & 2.14 \\
\hline Campania & South & Caserta & 1.54 & 1.42 & 0.12 & -7.78 & -3.24 \\
\hline Sardegna & South & Sassari & 1.01 & 0.84 & 0.17 & -0.92 & 3.61 \\
\hline Molise & South & Isernia & 1.46 & 1.20 & 0.26 & -2.87 & 1.67 \\
\hline Sicilia & South & Ragusa & 1.12 & 0.83 & 0.29 & -6.30 & -1.77 \\
\hline Abruzzo & South & Chieti & 1.32 & 1.00 & 0.32 & -6.22 & -1.69 \\
\hline Abruzzo & South & L'Aquila & 1.53 & 1.10 & 0.43 & -6.46 & -1.92 \\
\hline Abruzzo & South & Pescara & 1.49 & 1.04 & 0.45 & -5.23 & -0.69 \\
\hline Abruzzo & South & Teramo & 1.43 & 0.81 & 0.62 & -4.95 & -0.41 \\
\hline Lazio & Centre & Frosinone & 0.96 & 0.82 & 0.13 & -2.26 & 2.27 \\
\hline Lombardia & North & Sondrio & 1.12 & 0.87 & 0.25 & -5.05 & -0.51 \\
\hline Liguria & North & Genova & 1.32 & 0.99 & 0.33 & -9.37 & -4.84 \\
\hline Piemonte & North & Torino & 1.32 & 0.95 & 0.38 & -10.06 & -5.52 \\
\hline Veneto & North & Venezia & 1.47 & 1.07 & 0.40 & -5.75 & -1.21 \\
\hline Piemonte & North & Vercelli & 2.22 & 1.77 & 0.45 & -9.04 & -4.50 \\
\hline Piemonte & North & Biella & 1.55 & 1.10 & 0.45 & -1.88 & 2.66 \\
\hline Trentino-A.A. & North & Bolzano & 1.13 & 0.65 & 0.47 & -2.96 & 1.58 \\
\hline Friuli-V.G & North & Trieste & 1.58 & 1.11 & 0.47 & -9.32 & -4.78 \\
\hline Piemonte & North & Verb.-Cusio-Oss. & 1.54 & 1.06 & 0.48 & -6.30 & -1.77 \\
\hline Veneto & North & Rovigo & 1.47 & 0.98 & 0.49 & -8.65 & -4.12 \\
\hline Lazio & Centre & Latina & 1.61 & 1.10 & 0.51 & -3.02 & 1.52 \\
\hline Toscana & Centre & Massa-Carrara & 1.64 & 1.12 & 0.51 & -4.08 & 0.46 \\
\hline Veneto & North & Belluno & 1.49 & 0.97 & 0.51 & -4.07 & 0.46 \\
\hline Liguria & North & La Spezia & 1.91 & 1.35 & 0.56 & -10.24 & -5.70 \\
\hline
\end{tabular}


(Table A1) contd....

\begin{tabular}{|c|c|c|c|c|c|c|c|}
\hline Region & $\begin{array}{l}\text { Macro } \\
\text { Region }\end{array}$ & Province & $\begin{array}{c}\text { Average } \\
\text { In-Mirgation } \\
\text { Rate }\end{array}$ & $\begin{array}{c}\text { Average } \\
\text { Out-Migration } \\
\text { Rate }\end{array}$ & $\begin{array}{c}\text { Average } \\
\text { Net Migration } \\
\text { Rate }\end{array}$ & $\begin{array}{c}\text { Average } \\
\text { Unemployment } \\
\text { Growth Rate }\end{array}$ & $\begin{array}{l}\text { Distance from } \\
\text { National Unemployment } \\
\text { Growth Rate }\end{array}$ \\
\hline Lombardia & North & Milano & 1.89 & 1.33 & 0.57 & -6.42 & -1.88 \\
\hline Toscana & Centre & Livorno & 1.70 & 1.11 & 0.59 & -6.75 & -2.22 \\
\hline Veneto & North & Padova & 1.47 & 0.87 & 0.60 & -5.41 & -0.88 \\
\hline Lombardia & North & Varese & 1.81 & 1.19 & 0.63 & -4.74 & -0.20 \\
\hline Lazio & Centre & Roma & 1.61 & 0.97 & 0.64 & -4.79 & -0.26 \\
\hline Marche & Centre & Ascoli Piceno & 1.39 & 0.74 & 0.65 & -2.11 & 2.42 \\
\hline Piemonte & North & Alessandria & 1.93 & 1.26 & 0.67 & -6.00 & -1.46 \\
\hline Friuli-V.G & North & Udine & 1.50 & 0.83 & 0.67 & -6.69 & -2.16 \\
\hline Toscana & Centre & Lucca & 1.41 & 0.71 & 0.70 & -6.72 & -2.18 \\
\hline Lazio & Centre & Rieti & 2.16 & 1.46 & 0.70 & -5.07 & -0.53 \\
\hline Valle d'Aosta & North & Aosta & 1.87 & 1.16 & 0.70 & -3.27 & 1.26 \\
\hline Toscana & Centre & Firenze & 1.84 & 1.13 & 0.71 & -4.60 & -0.07 \\
\hline Emilia-Romagna & North & Ferrara & 1.69 & 0.97 & 0.73 & -4.27 & 0.26 \\
\hline Lombardia & North & Lecco & 1.90 & 1.17 & 0.73 & 0.89 & 5.43 \\
\hline Lombardia & North & Como & 1.87 & 1.13 & 0.74 & 0.75 & 5.28 \\
\hline Umbria & Centre & Terni & 1.61 & 0.87 & 0.74 & -7.29 & -2.75 \\
\hline Piemonte & North & Cuneo & 1.64 & 0.88 & 0.76 & -5.04 & -0.50 \\
\hline Liguria & North & Savona & 1.98 & 1.17 & 0.81 & -7.17 & -2.63 \\
\hline Liguria & North & Imperia & 2.14 & 1.28 & 0.87 & -6.96 & -2.42 \\
\hline Toscana & Centre & Grosseto & 1.89 & 1.02 & 0.87 & -5.44 & -0.91 \\
\hline Piemonte & North & Asti & 2.40 & 1.52 & 0.88 & -4.38 & 0.16 \\
\hline Veneto & North & Vicenza & 1.65 & 0.77 & 0.89 & -1.78 & 2.76 \\
\hline Marche & Centre & Ancona & 1.70 & 0.81 & 0.89 & -5.47 & -0.93 \\
\hline Friuli-V.G & North & Gorizia & 2.28 & 1.38 & 0.89 & -10.56 & -6.02 \\
\hline Piemonte & North & Novara & 2.24 & 1.33 & 0.91 & -3.09 & 1.45 \\
\hline Trentino-A.A. & North & Trento & 1.60 & 0.68 & 0.92 & -7.14 & -2.60 \\
\hline Lombardia & North & Bergamo & 1.64 & 0.72 & 0.92 & -0.59 & 3.95 \\
\hline Lombardia & North & Cremona & 2.10 & 1.14 & 0.95 & 1.30 & 5.84 \\
\hline Toscana & Centre & Prato & 2.56 & 1.56 & 1.00 & -4.14 & 0.40 \\
\hline Veneto & North & Verona & 1.72 & 0.71 & 1.00 & -4.27 & 0.26 \\
\hline Lazio & Centre & Viterbo & 2.15 & 1.13 & 1.01 & -6.43 & -1.90 \\
\hline Emilia-Romagna & North & Forlì-Cesena & 1.93 & 0.91 & 1.02 & -1.26 & 3.28 \\
\hline Toscana & Centre & Pisa & 2.08 & 1.05 & 1.03 & -6.55 & -2.01 \\
\hline Umbria & Centre & Perugia & 1.79 & 0.76 & 1.03 & -5.85 & -1.32 \\
\hline Emilia-Romagna & North & Pistoia & 2.13 & 1.10 & 1.03 & 1.60 & 6.14 \\
\hline Marche & Centre & Macerata & 1.99 & 0.95 & 1.04 & -3.06 & 1.48 \\
\hline Emilia-Romagna & North & Rimini & 2.14 & 1.10 & 1.04 & -5.63 & -1.09 \\
\hline Veneto & North & Treviso & 2.07 & 0.99 & 1.07 & -1.66 & 2.88 \\
\hline
\end{tabular}




\begin{tabular}{|c|c|c|c|c|c|c|c|}
\hline Region & $\begin{array}{l}\text { Macro } \\
\text { Region }\end{array}$ & Province & $\begin{array}{c}\text { Average } \\
\text { In-Mirgation } \\
\text { Rate }\end{array}$ & $\begin{array}{c}\text { Average } \\
\text { Out-Migration } \\
\text { Rate }\end{array}$ & $\begin{array}{c}\text { Average } \\
\text { Net Migration } \\
\text { Rate }\end{array}$ & $\begin{array}{c}\text { Average } \\
\text { Unemployment } \\
\text { Growth Rate }\end{array}$ & $\begin{array}{c}\text { Distance from } \\
\text { National Unemployment } \\
\text { Growth Rate }\end{array}$ \\
\hline Toscana & Centre & Arezzo & 1.92 & 0.84 & 1.08 & 1.40 & 5.94 \\
\hline Marche & Centre & Pesaro-Urbino & 1.93 & 0.85 & 1.09 & -3.27 & 1.27 \\
\hline Lombardia & North & Mantova & 2.24 & 1.14 & 1.09 & -3.06 & 1.48 \\
\hline Lombardia & North & Brescia & 1.79 & 0.67 & 1.12 & -1.37 & 3.17 \\
\hline Emilia-Romagna & North & Piacenza & 2.06 & 0.94 & 1.12 & -10.22 & -5.68 \\
\hline Emilia-Romagna & North & Bologna & 2.22 & 1.09 & 1.13 & -3.79 & 0.75 \\
\hline Lombardia & North & Pavia & 2.33 & 1.20 & 1.14 & -1.37 & 3.17 \\
\hline Emilia-Romagna & North & Modena & 2.39 & 1.25 & 1.14 & -2.28 & 2.25 \\
\hline Friuli-V.G & North & Pordenone & 2.21 & 1.07 & 1.14 & -4.21 & 0.32 \\
\hline Emilia-Romagna & North & Ravenna & 2.09 & 0.93 & 1.17 & -6.17 & -1.63 \\
\hline Toscana & Centre & Siena & 2.37 & 1.19 & 1.18 & -1.10 & 3.44 \\
\hline Lombardia & North & Lodi & 2.71 & 1.51 & 1.20 & -9.70 & -5.16 \\
\hline Emilia-Romagna & North & Parma & 2.35 & 0.98 & 1.36 & -5.04 & -0.50 \\
\hline Emilia-Romagna & North & Reggio Emilia & 2.82 & 1.10 & 1.72 & -0.67 & 3.86 \\
\hline
\end{tabular}

Notes: In-migration rate $=$ In-flow/population*100; Out-migration rate = Out-flow/population*100; Net-migration rate = In-migration rate minus Out-migration rate. We consider inflows, out-flows and population aged between 15 and 64 (i.e. working population).

\section{APPENDIX 2}

\section{The Spatial Weight Matrix}

In order to construct the spatial weight matrix, we have applied the k-nearest neighbours $(k-n n)$ criterion. In general, a matrix $k-n n, W(k)$ is constructed as follows:

$w_{r l}^{*}(k)=0 \quad$ if $r=1$ for each $k$

$w_{r l}^{*}(k)=1 \quad$ if $\mathrm{d}_{r l}<\mathrm{d}_{r}$ and $w_{r l}(k)=w_{r l}^{*}(k) / \sum_{j} w_{r l}^{*}(k)$

$w_{r l}^{*}(k)=0 \quad$ if $\mathrm{d}_{r l} \geq \mathrm{d}_{r}$

where $w_{r l}^{*}(k)$ is an element of the non-standardized weight matrix; $w_{r l}(k)$ is an element of the standardized weight matrix; $\mathrm{d}_{r}(k)$ is a critical cut-off distance defined for each unit $r$. More precisely, $\mathrm{d}_{r}(k)$ is the smaller distance of order $k$ between unit $r$ and the other territorial units such that each unit $r$ has exactly $k$ neighbours.

\section{REFERENCES}

[1] Blanchard OJ, Katz LF. Regional evolutions. Brookings Pap Econ Act 1992; 1: 1-75.

[2] Decressin J, Fatàs A. Regional labor market dynamics in Europe. Eur Econ Rev 1995; 39: 1627-55.

[3] Epifani P, Gancia GA. Trade, migration and regional unemployment. Reg Sci Urban Econ 2005; 35: 625-44.

[4] Suedekum J. Selective migration, union wage setting and unemployment disparities in West Germany. Int Econ J 2004; 18: 33-48.

[5] Faini R, Galli G, Gennari P, Rossi F. An empirical puzzle: falling migration and growing unemployment differentials among Italian regions. Eur Econ Rev 1997; 41: 571-9.
[6] Brunello G, Lupi C, Ordine P. Widening differences in Italian regional employment. Lab Econ 2001; 8: 103-29.

[7] Kostoris-Padoa-Schioppa F, Basile R. Unemployment dynamics in the 'Mezzogiornos of Europe': lessons for the Mezzogiorno of Italy", CEPR Discussion Paper 3594; 2002.

[8] Svimez. Rapporto sull'economia del Mezzogiorno. Il Mulino, Bologna, 2011

[9] Hong E, Sun L, Li T. Location of foreign direct investment in China: a spatial dynamic panel data analysis by country of origin. Discussion Paper 86, Department of Financial \& Management Studies, University of London, 2008.

[10] Kukenova M. Monteiro JA. Does lax environmental regulation attract FDI when accounting for "third-country" effects? Mimeo, 2009.

[11] Okui R. The optimal choice of moments in dynamic panel data models. Mimeo; 2008

[12] Overman HG, Puga D. Unemployment clusters across Europe's regions and countries. Econ Pol: A Eur Forum 2002; 34: 116-47.

[13] Chalmers JA, Greenwood MJ. The regional labor market adjustment process: determinants of changes in rates of labor force participation, unemployment, and migration. Ann Reg Sci 1985; 19: 1-17.

[14] Elhorst JP. The mystery of regional unemployment differentials: theoretical and empirical explanations. J Econ Surv 2003; 17: 70948.

[15] Harris JR, Todaro MP. Migration, unemployment and development: a two-sector analysis, Am Econ Rev 1970; 60: 12642 .

[16] Marston ST. Two views of the geographic distribution of unemployment. Quart J Econ 1985; 100: 57-79.

[17] Burda M, Wyplosz C. Human capital, investment and migration in an integrated Europe. Eur Econ Rev 1992; 36: 677-84.

[18] Basile R, Causi M. Le determinanti dei flussi migratori nelle province italiane: 1991-2000. Econ Lavoro 2007; 2: 139-59.

[19] Groenewold N. Does migration equalize regional unemployment rates? Evidence from Australia. Pap Reg Sci 1997; 76: 1-20.

[20] Wrage $P$. The regional effects of internal migration on regional wage and unemployment disparities in Canada. J Reg Sci 1981; 21: 51-63.

[21] Rutkowski J, Przybila M. Poland: Regional Dimensions of Unemployment. In: Funck B, Pizzati L, Eds. Labor, employment 
and social policy in the EU enlargement process. Changing perspectives and policy options. World Bank, Washington, DC, 2002: 157-75.

[22] Kertesi G. Migration and commuting: two potential forces reducing regional inequalities in economic opportunities? SOCO Project Paper 77a, Institute for Human Sciences; 2000.

[23] Loader CR. Local likelihood density estimation. Ann Stat 1996; 24: 1602-18.

[24] Daveri F, Faini R. Where do migrants go? Oxford Econ Pap 1999; 51: 595-622.

[25] Fachin S. Long-run trends in internal migrations in Italy: a study in panel cointegration with dependent units. J Appl Econom 2007; 22: 401-28.

[26] LeSage JP, Pace RK. Introduction to Spatial Econometrics. London, New York: Boca Raton: CRC Press Taylor \& Francis Group 2009.

[27] Bouayad-Agha S, Vedrine L. Estimation strategies for spatial dynamic panel using GMM. A new approach to the convergence issue of European regions. Mimeo; 2009.

[28] Yu J, Lee L. Convergence: a spatial dynamic panel data approach. Mimeo, 2009.

[29] Kapoor M, Kelejian H and Prucha IR. Panel data models with spatially correlated error components. J Econom 2007; 140: 97130.

[30] Lee LF, Yu J. A spatial dynamic panel data model with both time and individual fixed effects. Econom Theory 2010; 26: 564-97.
[31] Yu J, de Jong R, Lee L. Quasi-maximum likelihood estimators for spatial dynamic panel data with fixed effects when both $\mathrm{N}$ and $\mathrm{T}$ are large. J Econom 2008; 146: 118-34.

[32] Piras R. Internal migration across Italian regions: macroeconomic determinants and accommodating potential for a dualistic economy. Fondazione Eni Enrico Mattei Working Papers 504; 2010.

[33] Pesaran MH. A simple panel unit root test in the presence of cross section dependence. J Appl Econom 2007; 22: 265-312.

[34] Arellano M, Bond S. Some tests of specification for panel data: Monte Carlo evidence and an application to employment equations, Rev Econ Stud; 58: 277-97.

[35] Pissarides CA, McMaster I. Regional migration, wages and unemployment: empirical evidence and implications for policy. Oxford Econ Pap 1990; 42: 812-31.

[36] Westerlund O. Employment opportunities, wages and international migration in Sweden 1970-1989. J Reg Sci 1997; 37: 55-73.

[37] Jiwattanakulpaisarn P, Noland RB, Graham DJ, Polak JW. Highway infrastructure and state-level employment: a causal spatial analysis. Pap Reg Sci 2009; 88: 133-59.

[38] Windmeijer F. A finite sample correction for the variance of linear efficient two-step GMM estimators. J Econom 2005; 126: 25-51.

[39] Roodman D. A note on the theme of too many instruments. Oxford Bull Econ Stat 2009; 71: 135-58.

[40] Gordon I. In: Martin R, Morrison PS, Eds. Geographies of labor market inequality. London: Routledge 2003: 55-82.

[41] Mocetti S, Porello C. La mobilità del lavoro in Italia: nuove evidenze sulle dinamiche migratorie. Bank of Italy Occasional papers, $61 ; 2010$.

This is an open access article licensed under the terms of the Creative Commons Attribution Non-Commercial License (http://creativecommons.org/licenses/by$\mathrm{nc} / 3.0 /$ ) which permits unrestricted, non-commercial use, distribution and reproduction in any medium, provided the work is properly cited. 